\title{
Shallow genetic structure of three species of the genus Trachurus in European waters
}

\author{
Nikoletta Karaiskou, Alexander Triantafyllidis, Costas Triantaphyllidis*
}

Department of Genetics, Development and Molecular Biology, School of Biology, Aristotle University of Thessaloniki, 54124 Thessaloniki, Macedonia, Greece

\begin{abstract}
Pelagic marine fishes generally show little geographical population differentiation. Of special interest are marine species with Atlantic-Mediterranean distribution because of the possible effect of past and present day restrictions to gene flow between the 2 seas. Thus, restriction analysis of the whole control region (D-loop) of mitochondrial DNA (mtDNA) was used to extensively investigate the genetic structure of the 3 Trachurus species present both in Atlantic and Mediterranean waters: T. trachurus, T. mediterraneus and T. picturatus. In total, 666 individuals were screened from 5 Mediterranean and 6 Atlantic areas. Two African areas were also sampled for T. trachurus. No differentiation was revealed among European populations within the 3 studied species. Additionally, no sign of Atlantic-Mediterranean division was found, probably due to the fact that specific life history traits provide the Trachurus species with flexibility to oceanographical constraints and give them the ability to migrate long distances. Differentiation was only revealed between European and African populations of $T$. trachurus, reinforcing the existence of the $T$. trachurus capensis subspecies in African waters. Populations are probably under long and stable demographic equilibrium conditions as indicated by high haplotypic and nucleotide diversity values for all 3 species. Thus, mtDNA could be a powerful tool in determining the taxonomic distinctiveness of individual populations and species, and therefore, aid in setting priorities for future management policies. The present results are also discussed in comparison with the results of previous cytochrome b sequence analysis of the 3 Trachurus species.
\end{abstract}

KEY WORDS: Trachurus spp. $\cdot$ Mitochondrial DNA $\cdot$ D-loop $\cdot$ RFLP $\cdot$ Marine species $\cdot$ Mediterranean Resale or republication not permitted without written consent of the publisher

\section{INTRODUCTION}

Many marine organisms have exceptional dispersal and migratory capabilities; species ranges can be vast and their life history may include high fecundities and explosive reproductive potentials (e.g. Graves 1998, Grewe \& Hampton 1998). Although these features lead marine fishes to display a population structure that is characterized by a lack of significant heterogeneity even between ocean samples (e.g. Graves et al. 1984), striking differences have been found in certain cases (e.g. Kotoulas et al. 1995, Magoulas et al. 1996, Nesbø et al. 2000). These differences underscore the need for a thorough understanding of the genetic basis of population structure of marine species.

The degree of genetic differentiation between Atlantic and Mediterranean populations has been the subject of study for many marine organisms. In many cases, the Mediterranean and the adjacent Atlantic coasts support very similar faunas (reviews in Borsa et al. 1997b, Bargelloni et al. 2003). However, for a growing number of species, the Strait of Gibraltar has been proposed to be the geographical constraint between these 2 biogeographical regions. Evidence for this hypothesis has recently been provided by moderately strong to strong intraspecific genetic variation in a variety of species, e.g. the swordfish Xiphias gladius (Kotoulas et al. 1995), $75 \%$ of the species studied in a review by Borsa et al. (1997b), Platichthys flesus and $P$. stellatus (Borsa et al. 1997a), the mussel Mytilus galloprovincialis (Quesada et al. 1998), the sea bass Dicentrarchus labrax (Naciri et al. 1999), the krill Meganyctiphanes norvegica (Zane et al. 2000) and a number of sparid fishes (Bargelloni et al. 2003). These studies 
have shown restricted gene flow between Atlantic and Mediterranean populations. Hypotheses for the observed patterns of differentiation have included various models such as isolation by distance with limited gene flow and, alternatively, secondary contact of previously isolated and divergent populations (PerezLosada et al. 2002).

Three species of the genus Trachurus: T. trachurus, T. mediterraneus and T. picturatus, are found together in the Northeast Atlantic and Mediterranean waters and are commercially exploited in different water areas (following the International Council for the Exploration of the Sea [ICES] area divisions.) The species $T$. trachurus is commonly found in the waters off West Africa/Cape Verde Islands to the Norwegian Sea, including Iceland as well as the Mediterranean and Black Seas. It is the most northerly representative of the trachurid sub-family, which is widely distributed in the world's seas and often supports important fisheries. The other 2 species have a more restricted distribution expanding from the Bay of Biscay (France) southwards to Moroccan waters and eastwards in the Mediterranean Sea. T. mediterraneus is even found in the Marmara and the Black Seas (Froese \& Pauly 2001). The name horse mackerel is also used to describe the subspecies Trachurus trachurus capensis that is distributed in the eastern Atlantic from the Gulf of Guinea to South Africa. However, there are researchers that suggest that this is not a valid taxonomic group (Froese \& Pauly 2001).

Several studies have explored the biology and fisheries throughout the geographic range of the 3 Trachurus spp., especially of $T$. trachurus, with regard to reproduction and growth (e.g. Massé et al. 1996, Viette et al. 1997, Waldron \& Kerstan 2001, Abaunza et al. 2003). However, there are extremely few data on their genetic structure. The first published attempt (Karaiskou et al. 2003) was based on sequence data of the cytochrome b gene of mtDNA. This work shed light mostly on the phylogenetic relationships of the 3 Trachurus species and provided a possible scenario of the divergence time of the 3 species related to the closure of the Gibraltar Strait. Global and pairwise tests of population differentiation (based on restricted sampling) did not reveal significant differentiation for the 9 European studied areas of the 3 Trachurus species.

Thus, the present study attempts to thoroughly investigate the genetic structure of the 3 Trachurus species populations (in an extensive sampling scheme) from the Mediterranean and Atlantic Seas, by means of restriction fragment length polymorphism (RFLP) analysis of a PCR-amplified mitochondrial DNA (mtDNA) region. Since different regions of mtDNA evolve at different rates, specific mtDNA genes have been targeted for phylogeny reconstruction (Hillis et al. 1996), species identification and assays of intraspecific variation (Chow et al. 1993, Bembo et al. 1995). One of the mtDNA regions that has often been used is the control region (D-loop region). The rate of evolution of the D-loop region is reputedly 2 to 5 times higher than that of mitochondrial protein coding genes (Meyer 1993) and for this reason is the molecule of choice for the study of population level phenomena.

The primary objective of this study is to test whether the Strait of Gibraltar constitutes a constraint in the free movement of the 3 Trachurus species ( $T$. trachurus, T. mediterraneus and T. picturatus) leading to the accumulation of genetic differences among Atlantic and Mediterranean populations. A further and more general objective is to see if genetic differences can even be detected among local Trachurus populations within the Mediterranean and the Atlantic Seas. Furthermore, this study aims to determine the genetic divergence and the phylogenetic relationships of the 3 Trachurus species. These objectives have obvious implications for the understanding of the population biology of the 3 species and their proper management.

\section{MATERIALS AND METHODS}

Sample collection. Samples of the 3 Trachurus species were collected from 5 Mediterranean regions and 6 regions from the Atlantic Sea (Table $1 \&$ Fig. 1). Samples of $T$. trachurus were also obtained from Namibia and South Africa, and samples of T. trecae from the area of Cadiz (Portugal) were also included in the analysis as an outgroup.

DNA extraction, PCR amplification and restriction enzyme digestion. White muscle tissue was taken from each individual and either stored at $-20^{\circ} \mathrm{C}$ or kept in absolute ethanol. DNA was extracted according to the protocol of Taggart et al. (1992). Overall, 12 geographic samples of Trachurus trachurus (344 individuals), 6 samples of $T$. mediterraneus (182 individuals) and 5 samples of $T$. picturatus (140 individuals) were screened for polymorphism in the D-loop region. In total, 666 individuals were analyzed. In addition, 12 individuals of $T$. trecae were scored.

The whole control region (D-loop) was amplified using primers that were designed based on the published sequence of the whole control region of $T$. trachurus under the Accession number AF271658. Primers were designed using the programme Primer3 (Rozen \& Skaletsky 2000). PCR amplifications were performed using the Dloop-H (5'-CCAGTCTTGTAAACCGAATGC-3') and Dloop-L primers (5'GGGCCCATCTTAACATCTTC-3') that bind at the tRNA $^{\text {Thr }}$ and at the tRNA ${ }^{\text {Phe }}$ genes, respectively. They amplify the tRNA $^{\text {Prol }}$ and the whole control region, 
Table 1. Trachurus spp. Sampling sites, sampling date and number of individuals $(\mathrm{N})$ analyzed from every region

\begin{tabular}{|c|c|c|c|c|}
\hline Species & $\begin{array}{l}\text { Sampling } \\
\text { area }\end{array}$ & $\begin{array}{l}\text { ICES } \\
\text { division }\end{array}$ & $\begin{array}{c}\text { Sampling } \\
\text { date }\end{array}$ & $\mathrm{N}$ \\
\hline \multicolumn{5}{|c|}{ T. mediterraneus } \\
\hline & N Aegean & - & $05 / 00$ & 37 \\
\hline & S Aegean & - & $06 / 00$ & 32 \\
\hline & Ionian & - & 09/00 & 32 \\
\hline & W Italy & - & $10 / 02$ & 16 \\
\hline & E Spain & - & $09 / 00$ & 35 \\
\hline & Portugal & (IXa) & 06/01 & 30 \\
\hline \multicolumn{5}{|c|}{ T. trachurus } \\
\hline & N Aegean & - & 08/01 & 30 \\
\hline & S Aegean & - & $10 / 01$ & 63 \\
\hline & Ionian & - & 05/01 & 29 \\
\hline & W Italy & - & $10 / 02$ & 18 \\
\hline & Portugal & (IXa) & 06/02 & 29 \\
\hline & N Spain & (VIIIC) & $08 / 00$ & 30 \\
\hline & NW Spain & (VIIIb) & 08/02 & 32 \\
\hline & NW France & (VIIe) & $04 / 00$ & 12 \\
\hline & SE England & $(\mathrm{IVb}-\mathrm{c})$ & 08/02 & 29 \\
\hline & W Norway & (IVa) & $05 / 02$ & 30 \\
\hline & South Africa & - & 08/02 & 20 \\
\hline & Namibia & - & $08 / 02$ & 22 \\
\hline \multicolumn{5}{|c|}{ T. picturatus } \\
\hline & N Aegean & - & $05 / 00$ & 30 \\
\hline & S Aegean & - & 09/00 & 31 \\
\hline & Ionian & - & 06/01 & 31 \\
\hline & W Italy & - & $10 / 02$ & 19 \\
\hline & Portugal & (IXa) & 06/01 & 29 \\
\hline Total & & & & 666 \\
\hline
\end{tabular}

giving a $1030 \mathrm{bp}$ PCR product. Double-stranded DNA amplification was performed in $50 \mathrm{ml}$ reaction volumes containing 2 units of Taq polymerase, $5 \mathrm{ml}$ of $10 \times$ Reaction Buffer, $2.5 \mathrm{mM} \mathrm{MgCl}_{2}, 0.25 \mathrm{mM}$ dNTPs, 40 pmol of each primer and approximately 50 to $100 \mathrm{ng}$ of template DNA.

Thermal cycling amplification conditions were as follows: initial denaturation at $95^{\circ} \mathrm{C}$ for $4 \mathrm{~min}$, followed by 31 cycles of strand denaturation at $94^{\circ} \mathrm{C}$ for $45 \mathrm{~s}$, annealing at $51^{\circ} \mathrm{C}$ for $45 \mathrm{~s}$ and primer extension at $72^{\circ} \mathrm{C}$ for $45 \mathrm{~s}$, and a final 5 min elongation time at $72^{\circ} \mathrm{C}$. The size of the PCR products was checked against a 100-bp DNA ladder (Gibco BRL) in 1.5\% agarose gel, run in $1 \times$ TBE buffer and stained with $0.5 \mathrm{mg} \mathrm{ml}^{-1}$ ethidium bromide.

Mitochondrial DNA variation was analyzed by restriction fragment length polymorphism (RFLP) performed on PCR-amplified products. The amplified fragments were initially screened for polymorphism with the following 12 restriction endonucleases: Bst UI, BstNI, HaeIII, MspI, RsaI, SspI, DdeI, HhaI, HincII, HinfI, NlaIII and TaqI. For each sample, 5-10 ml of the PCR product was digested with the appropriate restriction enzyme. The digested samples were then electrophoretically separated on $2 \%$ agarose gels in $1 \times$
TBE buffer, stained with ethidium bromide, visualized under UV light and the size of the fragments was estimated relative to a standard 100 bp DNA ladder (Gibco BRL).

Scoring of variation. The raw data were fragment profiles, but we inferred site differences among haplotypes from changes in fragment profiles and based on a limited number of obtained sequences (not shown). All RFLPs could be explained by the gain or loss of particular restriction sites. For each RFLP pattern observed for each enzyme, a presence/absence restriction site matrix was created. Distinct single endonuclease patterns were identified by a specific letter in order of appearance. Each specimen was assigned a multiletter code that described its composite mtDNA genotype. Restriction patterns are available upon request.

Data analysis. Haplotype diversity (Nei 1987) and nucleotide diversity (Nei \& Tajima 1981) values within samples, as well as nucleotide divergence (Nei \& Tajima 1981) values between haplotypes and samples were computed using the statistical package REAP 4.0 (McElroy et al. 1991). The global and pairwise sample differentiation was assessed using exact tests (Raymond \& Rousset 1995) included in the ARLEQUIN package (Schneider et al. 2000). Corrections for simultaneous multiple comparisons were applied using sequential Bonferroni correction (Rice 1989). Analysis of molecular variance (AMOVA, Excoffier et al. 1992) was used to estimate the amount of genetic structuring at different

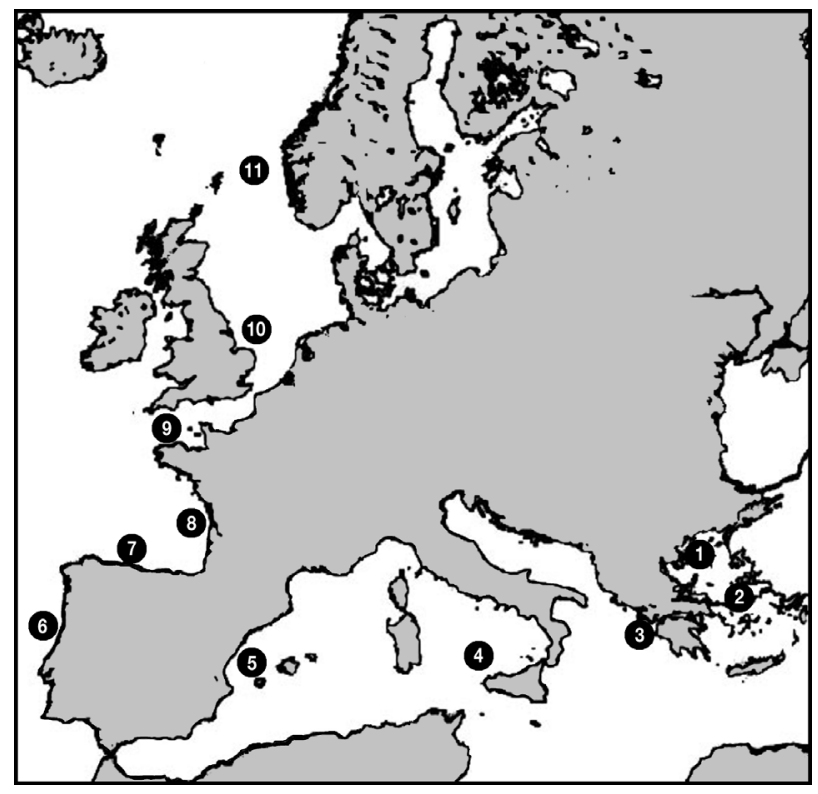

Fig 1. European waters where the different sampling areas (some with ICES divisions) are shown. 1: N Aegean Sea; 2: S Aegean Sea; 3: Ionian Sea; 4: W Italy; 5: E Spain; 6: IXa (Portugal); 7: VIIIe (N Spain); 8: VIIIb (NW Spain); 9: VIIe (NW France); 10: IVb-C (SE England); 11: IVa (N Norway) 
hierarchical levels by quantifying the inter- and intragroup component of total variance by Fstatistics in the ARLEQUIN package (Schneider et al. 2000). The significance of the resultant $F$-statistics and variance components were tested with 10000 permutations.

Both distance and character-based approaches included in PHYLIP version 3.57c (Felsenstein 1995) were used to find relationships among haplotypes. Genetic distances among haplotypes from restriction site data were used to construct a UPGMA tree (Saitou \& Nei 1987) using the NEIGHBOR program. A FITCH (distance) phenogram was also constructed using the FITCH program. Wagner parsimony analysis was also performed using the MIX program contained in the PHYLIP program. The topology of the consensus tree constructed with the CONSENSE program was evaluated by 1000 bootstrap replications using the SEQBOOT program. In all cases, trees were rooted using as an outgroup the species Trachurus trecae. UPGMA phenograms that cluster samples according to nucleotide divergence were constructed with the NEIGHBOR programme included in PHYLIP.

In order to test for isolation by distance, a Mantel test (Mantel 1967), with 10000 random permutations, was carried out with the GENETIX package (Belkhir 1999).

\section{RESULTS}

\section{Initial experiments with 12 restriction enzymes}

The amplified segments of the tRNA ${ }^{\text {Pro }}$ and the whole control region had an approximate size of $1030 \mathrm{bp}$. All the restriction enzymes used to screen the 23 samples have at least 1 recognition site on the

Table 2. Trachurus trachurus. Composite haplotypes, haplotype frequency, nucleotide and haplotype diversity values (\%) including standard error (SE), and sample sizes of the studied populations (species-specific haplotypes of African T. trachurus are marked in bold). Composite haplotypes are denoted by capital letters in the following order: DdeI, HhaI, HinfI, NlaIII, HincII, TaqI. Roman numerals refer to the following areas: IXa (Portugal), VIIIc (N Spain), VIIIb (NW Spain), VIIe (NW France), IVb-c (SE England), IVa (W Norway); see also Fig. 1. Capital letters of composite haplotypes refer to different patterns obtained for each restriction enzyme

\begin{tabular}{|c|c|c|c|c|c|c|c|c|c|c|c|c|c|}
\hline \multirow{2}{*}{$\begin{array}{l}\text { Haplo- } \\
\text { type }\end{array}$} & \multirow{2}{*}{$\begin{array}{l}\text { Trachurus trachurus } \\
\text { composite haplotype }\end{array}$} & \multirow[b]{2}{*}{$\begin{array}{l}\text { North } \\
\text { Aegean }\end{array}$} & \multirow[b]{2}{*}{$\begin{array}{l}\text { South } \\
\text { Aegean }\end{array}$} & \multirow[b]{2}{*}{ Ionian } & \multirow[b]{2}{*}{$\begin{array}{l}\text { West } \\
\text { Italy }\end{array}$} & \multirow[b]{2}{*}{ IXa } & \multicolumn{2}{|c|}{ Sample locality } & \multirow[b]{2}{*}{ VIIe } & \multirow[b]{2}{*}{ IVa } & \multirow[b]{2}{*}{$\mathrm{IVb}-\mathrm{C}$} & \multirow[b]{2}{*}{$\begin{array}{l}\text { South } \\
\text { Africa }\end{array}$} & \multirow[b]{2}{*}{ Namibia } \\
\hline & & & & & & & VIIIC & VIIIb & & & & & \\
\hline T.t. 1 & $\mathrm{C} \quad \mathrm{B} \quad \mathrm{B} \quad \mathrm{C} \quad \mathrm{D} \quad \mathrm{A}$ & 2 & 2 & & & & & & & & 1 & & \\
\hline T.t. 2 & $\mathrm{C} B \mathrm{~A} \quad \mathrm{C}$ D A & 1 & 7 & 3 & 3 & & 1 & 3 & 2 & & & & \\
\hline T.t. 3 & $\mathrm{~B} \quad \mathrm{~B} \quad \mathrm{~B} \quad \mathrm{~A} \quad \mathrm{D} \quad \mathrm{A}$ & 10 & 13 & 9 & 4 & 11 & 8 & 6 & 3 & 9 & 6 & & \\
\hline T.t. 4 & $\mathrm{~B} B \mathrm{~A} \quad \mathrm{C}$ D A & 2 & 2 & 1 & 1 & & & 1 & 1 & & & & \\
\hline T.t. 5 & $\mathrm{C} B \mathrm{~B} \quad \mathrm{~A} \quad \mathrm{D} A$ & 4 & 5 & 3 & 4 & 4 & 8 & & 2 & 5 & 4 & & \\
\hline T.t. 6 & $\mathrm{C} B \mathrm{~A} A \mathrm{D} \quad \mathrm{B}$ & & 1 & & & & & & & & & & \\
\hline T.t. 7 & $\mathrm{~B} B \mathrm{~A} A \mathrm{D} A$ & 6 & 18 & 8 & 2 & 7 & 7 & 10 & 2 & 7 & 14 & & \\
\hline T.t. 8 & $\mathrm{C} B \mathrm{~A} A \mathrm{D} A$ & 4 & 8 & 4 & 2 & 5 & 4 & 11 & 2 & 8 & 3 & & \\
\hline T.t. 9 & I $\mathrm{B} A \mathrm{~A} \quad \mathrm{D} A$ & 1 & & & & & 1 & & & & 1 & & \\
\hline T.t. 10 & 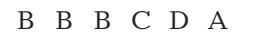 & & 3 & 1 & & 1 & & & & & & & \\
\hline T.t. 11 & $\mathrm{G} B \mathrm{~B} \quad \mathrm{C} \quad \mathrm{D} A$ & & 1 & & & & & & & & & & \\
\hline T.t. 12 & B $B$ A $G$ D A & & 2 & & & & & & & & & & \\
\hline T.t. 13 & $\mathrm{~B} B \mathrm{~A} \quad \mathrm{~F} \mathrm{D} A$ & & 1 & & & & & & & & & & \\
\hline T.t. 14 & $\mathrm{P} \quad \mathrm{B} \quad \mathrm{B} \quad \mathrm{A} \quad \mathrm{D} A$ & & & & & & & 1 & & & & & \\
\hline T.t. 15 & $\mathrm{~K} B \mathrm{~A} A \mathrm{~A} A$ & & & & & & & & & 1 & & & \\
\hline T.t. 16 & B $B$ A $\quad C \quad D \quad B$ & & & & & & 1 & & & & & & \\
\hline T.t. 17 & $\mathrm{G} B \mathrm{~A} A \mathrm{D} A$ & & & & 1 & 1 & & & & & & & \\
\hline T.t. 18 & $\mathrm{C} B \mathrm{~A} \quad \mathrm{~F}$ D A & & & & 1 & & & & & & & & \\
\hline T.t. 19 & 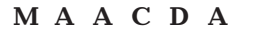 & & & & & & & & & & & & 1 \\
\hline T.t. 20 & $\begin{array}{llllll}\mathbf{N} & \mathbf{A} & \mathbf{B} & \mathbf{A} & \mathbf{D} & \mathbf{A}\end{array}$ & & & & & & & & & & & 3 & 13 \\
\hline T.t. 21 & $\begin{array}{llllll}\mathbf{N} & \mathbf{A} & \mathbf{A} & \mathbf{A} & \mathbf{D} & \mathbf{A}\end{array}$ & & & & & & & & & & & 7 & 2 \\
\hline T.t. 22 & $\mathbf{M} \mathbf{A} \mathbf{A} \mathbf{A} \quad \mathbf{D} \mathbf{A}$ & & & & & & & & & & & 6 & 1 \\
\hline T.t. 23 & 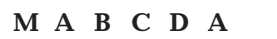 & & & & & & & & & & & & 3 \\
\hline T.t. 24 & $\begin{array}{llllll}\mathbf{M} & \mathbf{A} & \mathbf{B} & \mathbf{A} & \mathbf{D} & \mathbf{A}\end{array}$ & & & & & & & & & & & 2 & 1 \\
\hline T.t. 25 & $\mathbf{N} A \mathbf{A} \quad \mathbf{C}$ D $\mathbf{A}$ & & & & & & & & & & & & 1 \\
\hline T.t. 26 & $\begin{array}{llllll}\mathbf{N} & \mathbf{A} & \mathbf{B} & \mathbf{C} & \mathbf{D} & \mathbf{A}\end{array}$ & & & & & & & & & & & 1 & \\
\hline T.t. 27 & M C A A D A & & & & & & & & & & & 1 & \\
\hline Nucleot & e diversity (\%) & 0.98 & 1.15 & 0.93 & 1.18 & 0.80 & 0.93 & 0.84 & 1.08 & 0.78 & 0.75 & 0.89 & 0.88 \\
\hline Haploty & diversity (\%) & 82.99 & 84.84 & 81.28 & 88.89 & 77.34 & 80.92 & 76.21 & 89.39 & 78.16 & 71.67 & 78.95 & 64.50 \\
\hline$\pm \mathrm{SE}(\%$ & & 4.27 & 2.51 & 4.09 & 4.16 & 4.58 & 3.35 & 4.02 & 5.37 & 2.98 & 6.75 & 5.71 & 10.87 \\
\hline Total sa & ole size & 30 & 63 & 29 & 18 & 29 & 30 & 32 & 12 & 30 & 29 & 20 & 22 \\
\hline
\end{tabular}


amplified segment. A total of 132 individuals of the species Trachurus trachurus (41 European and 12 African specimens), T. mediterraneus (41) and T. picturatus (38) were initially scored with all 12 enzymes. Two of the restriction enzymes used for the RFLP analysis (Bst UI and Bst NI) did not reveal polymorphism, 4 of them (HaeIII, MspI, RsaI and SspI) revealed very low levels of polymorphism and the remaining 6 (DdeI, HhaI, HincII, HinfI, NlaIII and TaqI) discovered high levels of polymorphism. Additionally, 12 individuals of $T$. trecae were scored that generated totally different restriction patterns in 10 out of the 12 enzymes used (except for Bst NI and HinfI).

\section{RFLP analysis with 6 enzymes}

The 6 enzymes that discovered high levels of polymorphism were used to screen more individuals from all 3 studied species. An additional 534 individuals were scored, and 27, 25 and 25 haplotypes were generated in total for Trachurus trachurus, T. mediterraneus and $T$. picturatus, respectively (Tables $2,3 \& 4$ ). Nine of the 27 T. trachurus haplotypes were present in T. trachurus from Namibia and South Africa and were totally different from the haplotypes present in European Trachurus samples (Table 2).

There were restriction enzymes that produced species-specific patterns. Specifically, HhaI produced patterns in European Trachurus trachurus that were never present in the African T. trachurus or in the other 2 species and thus, produced composite haplotypes that could be used as diagnostic between European and African samples of $T$. trachurus as well as between the 3 studied species. Also, DdeI could be characterized as species-specific for $T$. trachurus as it could discriminate it from the other 2 species. The composite haplotypes with the absolute haplotype frequencies within each sampling site and the different restriction patterns that could be used to discriminate the 3 species are presented in Tables 2, 3 \& 4 .

Table 3. Trachurus mediterraneus. Composite haplotypes, haplotype frequency, nucleotide and haplotype diversity values (\%) including standard error (SE), and sample sizes of the studied populations. Composite haplotypes are denoted by capital letters in the following order: DdeI, HhaI, HinfI, sNlaIII, HincII, TaqI. Roman numerals refer to the following area: IXa (Portugal); see also Fig. 1. Capital letters of composite haplotypes refer to different patterns obtained for each restriction enzyme

\begin{tabular}{|c|c|c|c|c|c|c|c|c|c|c|c|c|}
\hline \multirow{3}{*}{$\begin{array}{l}\text { Haplotype } \\
\text { T.m. } 1\end{array}$} & \multirow{2}{*}{\multicolumn{6}{|c|}{$\begin{array}{l}\text { Trachurus mediterraneus } \\
\text { composite haplotype }\end{array}$}} & \multirow{3}{*}{$\frac{\text { N Aegean }}{5}$} & \multirow{3}{*}{$\frac{\text { S Aegean }}{6}$} & \multicolumn{2}{|c|}{ Sample locality } & \multirow{3}{*}{$\frac{\text { E Spain }}{8}$} & \multirow{3}{*}{$\frac{\text { IXa }}{4}$} \\
\hline & & & & & & & & & \multirow{2}{*}{$\frac{\text { Ionian }}{5}$} & \multirow{2}{*}{$\frac{\text { W Italy }}{2}$} & & \\
\hline & A & A & $\mathrm{A}$ & $\mathrm{E}$ & $\mathrm{A}$ & A & & & & & & \\
\hline T.m. 2 & A & A & $\mathrm{A}$ & $\mathrm{A}$ & $\mathrm{A}$ & A & 3 & 3 & 2 & & 2 & 2 \\
\hline T.m. 3 & A & A & $\mathrm{A}$ & B & $\mathrm{A}$ & A & 17 & 18 & 12 & 9 & 14 & 15 \\
\hline T.m. 4 & A & A & $\mathrm{A}$ & B & $\mathrm{A}$ & B & 2 & 2 & 1 & 1 & 1 & \\
\hline T.m. 5 & $\mathrm{H}$ & A & A & B & A & A & 1 & & 1 & & & \\
\hline T.m. 6 & A & A & A & B & B & B & 2 & & & & & \\
\hline T.m. 7 & A & A & A & $\mathrm{G}$ & A & A & 1 & & & & & \\
\hline T.m. 8 & $\mathrm{D}$ & $\mathrm{C}$ & A & B & $\mathrm{A}$ & A & 1 & & & & & \\
\hline T.m. 9 & A & A & $\mathrm{A}$ & $\mathrm{C}$ & A & B & 1 & & & & & 1 \\
\hline T.m. 10 & A & A & $\mathrm{A}$ & B & B & A & 1 & & & & & \\
\hline T.m. 11 & A & A & $\mathrm{A}$ & $\mathrm{E}$ & A & B & 1 & 1 & & & 3 & \\
\hline T.m. 12 & $\mathrm{D}$ & A & $\mathrm{A}$ & $\mathrm{E}$ & A & A & 1 & 1 & & & 1 & 1 \\
\hline T.m. 13 & $\mathrm{D}$ & A & $\mathrm{A}$ & B & $\mathrm{A}$ & A & 1 & 1 & 3 & 1 & 4 & 2 \\
\hline T.m. 14 & $\mathrm{D}$ & $\mathrm{C}$ & A & A & A & A & & & 1 & & & \\
\hline T.m. 15 & A & A & A & B & $\mathrm{D}$ & A & & & 1 & & & 1 \\
\hline T.m. 16 & A & A & A & $\mathrm{C}$ & A & A & & & 4 & & & 2 \\
\hline T.m. 17 & A & A & $\mathrm{A}$ & $\mathrm{F}$ & $\mathrm{A}$ & A & & & 1 & & & \\
\hline T.m. 18 & A & A & $\mathrm{A}$ & $\mathrm{G}$ & $\mathrm{F}$ & A & & & 1 & & & \\
\hline T.m. 19 & $\mathrm{O}$ & A & $\mathrm{A}$ & $\mathrm{A}$ & $\mathrm{D}$ & A & & & & & 1 & \\
\hline T.m. 20 & $\mathrm{O}$ & A & $\mathrm{A}$ & $\mathrm{A}$ & $\mathrm{A}$ & A & & & & & 1 & \\
\hline T.m. 21 & A & $\mathrm{C}$ & $\mathrm{A}$ & B & $\mathrm{A}$ & A & & & & 1 & & \\
\hline T.m. 22 & $\mathrm{D}$ & A & $\mathrm{A}$ & $\mathrm{H}$ & $\mathrm{C}$ & A & & & & 1 & & \\
\hline T.m. 23 & $\mathrm{H}$ & $\mathrm{C}$ & $\mathrm{A}$ & $\mathrm{E}$ & $\mathrm{A}$ & A & & & & 1 & & \\
\hline T.m. 24 & $\mathrm{D}$ & A & $\mathrm{A}$ & A & $\mathrm{D}$ & A & & & & & & 1 \\
\hline T.m. 25 & $\mathrm{D}$ & A & A & $\mathrm{A}$ & $\mathrm{A}$ & A & & & & & & 1 \\
\hline \multicolumn{7}{|c|}{ Nucleotide diversity (\%) } & 0.91 & 0.61 & 1.15 & 1.04 & 0.99 & 0.99 \\
\hline \multicolumn{7}{|c|}{ Haplotype diversity (\%) } & 77.33 & 65.32 & 82.66 & 69.17 & 78.32 & 73.79 \\
\hline \multicolumn{7}{|l|}{$\pm \mathrm{SE}(\%)$} & 6.63 & 8.14 & 5.24 & 12.8 & 5.15 & 8.02 \\
\hline \multicolumn{7}{|c|}{ Total sample size } & 37 & 32 & 32 & 16 & 35 & 30 \\
\hline
\end{tabular}


Table 4. Trachurus picturatus. Composite haplotypes, haplotype frequency, nucleotide and haplotype diversity values (\%) including standard error (SE), and sample sizes of the studied populations. Composite haplotypes are denoted by capital letters in the following order: DdeI, HhaI, HinfI, NlaIII, HincII, TaqI. Roman numerals refer to the following area: IXa (Portugal); see also Fig. 1. Capital letters of composite haplotypes refer to different patterns obtained for each restriction enzyme

\begin{tabular}{|c|c|c|c|c|c|c|c|c|c|c|c|}
\hline \multirow{2}{*}{$\begin{array}{l}\text { Haplotype } \\
\text { T.p. } 1\end{array}$} & \multicolumn{6}{|c|}{$\begin{array}{l}\text { Trachurus picturatus } \\
\text { composite haplotype }\end{array}$} & \multicolumn{5}{|c|}{\begin{tabular}{cc}
\multicolumn{3}{c}{ Sample locality } \\
S Aegean $\quad$ Ionian
\end{tabular}} \\
\hline & $\mathrm{D}$ & A & A & $\mathrm{C}$ & A & B & 4 & 6 & 7 & 7 & 3 \\
\hline T.p. 2 & $\mathrm{D}$ & A & A & $\mathrm{C}$ & B & B & 6 & 4 & 6 & 3 & 5 \\
\hline T.p. 3 & $\mathrm{D}$ & A & A & $\mathrm{C}$ & A & A & 4 & 6 & 7 & 6 & 5 \\
\hline T.p. 4 & $\mathrm{D}$ & A & A & $\mathrm{C}$ & B & A & 1 & 1 & 1 & 1 & \\
\hline T.p. 5 & $\mathrm{D}$ & $\mathrm{A}$ & A & $\mathrm{C}$ & $\mathrm{D}$ & B & 2 & 1 & 3 & & 3 \\
\hline T.p. 6 & $\mathrm{D}$ & $\mathrm{A}$ & A & $\mathrm{C}$ & $\mathrm{D}$ & $\mathrm{A}$ & 2 & 1 & 4 & & 1 \\
\hline T.p. 7 & $\mathrm{E}$ & $\mathrm{A}$ & A & $\mathrm{C}$ & A & $\mathrm{A}$ & & & 1 & & \\
\hline T.p. 8 & $\mathrm{D}$ & $\mathrm{A}$ & A & A & $\mathrm{D}$ & B & 1 & 1 & 1 & & 4 \\
\hline T.p. 9 & $\mathrm{D}$ & $\mathrm{A}$ & A & A & A & $\mathrm{A}$ & 1 & 1 & 1 & & 2 \\
\hline T.p. 10 & $\mathrm{E}$ & $\mathrm{A}$ & B & $\mathrm{C}$ & A & B & & 1 & & & \\
\hline T.p. 11 & $\mathrm{D}$ & $\mathrm{A}$ & A & $\mathrm{C}$ & $\mathrm{E}$ & B & & 1 & & & 1 \\
\hline T.p. 12 & $\mathrm{D}$ & $\mathrm{A}$ & A & $\mathrm{C}$ & $\mathrm{C}$ & $\mathrm{A}$ & & 1 & & & \\
\hline T.p. 13 & $\mathrm{D}$ & $\mathrm{A}$ & A & $\mathrm{D}$ & B & B & 3 & 1 & & 1 & \\
\hline T.p. 14 & $\mathrm{D}$ & $\mathrm{A}$ & A & $\mathrm{D}$ & A & B & 1 & & & & \\
\hline T.p. 15 & $\mathrm{D}$ & $\mathrm{A}$ & A & A & A & B & 2 & 1 & & 1 & 1 \\
\hline T.p. 16 & $\mathrm{D}$ & $\mathrm{C}$ & A & A & A & B & 1 & & & & \\
\hline T.p. 17 & $\mathrm{D}$ & $\mathrm{A}$ & A & $\mathrm{F}$ & $\mathrm{D}$ & B & 1 & 1 & & & \\
\hline T.p. 18 & $\mathrm{D}$ & $\mathrm{A}$ & A & $\mathrm{F}$ & A & B & 1 & & & & \\
\hline T.p. 19 & $\mathrm{~F}$ & A & A & $\mathrm{C}$ & A & B & & 1 & & & \\
\hline T.p. 20 & $\mathrm{D}$ & $\mathrm{A}$ & A & $\mathrm{E}$ & A & A & & 1 & & & \\
\hline T.p. 21 & $\mathrm{D}$ & $\mathrm{A}$ & A & $\mathrm{D}$ & $\mathrm{D}$ & $\mathrm{B}$ & & 1 & & & \\
\hline T.p. 22 & $\mathrm{D}$ & $\mathrm{A}$ & A & $\mathrm{F}$ & $\mathrm{B}$ & $\mathrm{B}$ & & 1 & & & \\
\hline T.p. 23 & $\mathrm{D}$ & $\mathrm{A}$ & $\mathrm{A}$ & A & $\mathrm{D}$ & $\mathrm{A}$ & & & & & 2 \\
\hline T.p. 24 & $\mathrm{D}$ & $\mathrm{A}$ & $\mathrm{A}$ & $\mathrm{A}$ & B & B & & & & & 1 \\
\hline T.p. 25 & $\mathrm{D}$ & $\mathrm{C}$ & $\mathrm{A}$ & $\mathrm{A}$ & $\mathrm{B}$ & $\mathrm{B}$ & & & & & 1 \\
\hline \multicolumn{7}{|c|}{ Nucleotide diversity (\%) } & 1.54 & 1.53 & 1.25 & 0.71 & 1.60 \\
\hline \multicolumn{7}{|c|}{ Haplotype diversity (\%) } & 92.41 & 92.26 & 85.81 & 77.19 & 91.63 \\
\hline \multicolumn{7}{|l|}{$\pm \mathrm{SE}(\%)$} & 2.59 & 3.02 & 2.98 & 6.22 & 2.45 \\
\hline \multicolumn{7}{|c|}{ Total sample size } & 30 & 31 & 31 & 19 & 29 \\
\hline
\end{tabular}

\section{Phylogenetic relationships of haplotypes}

Pairwise sequence divergence between haplotypes revealed after restriction analysis with the 6 enzymes that discovered polymorphism, ranged between 0.68 to $6.39 \%$ for Trachurus trachurus (when African samples of T. trachurus were not included in the analysis, the maximum value decreased to $4.10 \%$ ), 0.62 to $6.39 \%$ for $T$. mediterraneus and 0.59 to $4.55 \%$ for $T$. picturatus. After the addition of the 6 mostly monomorphic enzymes, the pairwise sequence divergence values for the 12 enzymes were lower and ranged between 0.38 to $3.76 \%$ for $T$. trachurus (when African samples of $T$. trachurus were not included in the analysis, the maximum value decreased to $2.64 \%$ ), 0.39 to $3.10 \%$ for T. mediterraneus and 0.35 to $2.87 \%$ for $T$. picturatus.

A UPGMA tree based on Nei's divergence values between 78 haplotypes, estimated after the analysis of all individuals of the 3 studied species is presented in Fig. 2. These haplotypes clustered in 2 main groups. One group included the haplotypes of Trachurus mediterraneus and T. picturatus, whereas the second group included the lineage of $T$. trachurus. The T. trachurus group was divided in 2 subgroups: one including the haplotypes present in European populations and the other consisting of the haplotypes present in African populations. The topology of the tree was not supported by high bootstrap values. The maximum parsimony method gave the same grouping of haplotypes. The FITCH (distance) phenogram (not shown) resulted in the same topology with the exception that the T. trecae outgroup was placed between the 2 groups of $T$. trachurus haplotypes.

\section{Sample diversity}

The number of observed haplotypes within samples varied from 6 to 12 for Trachurus trachurus, 7 to 17 for T. mediterraneus and 6 to 18 for T. picturatus. Three haplotypes (with total frequency $61.3 \%$ ) were common for all European samples of T. trachurus, 2 haplotypes (with total frequency $57.6 \%$ ) for $T$. mediterraneus and 


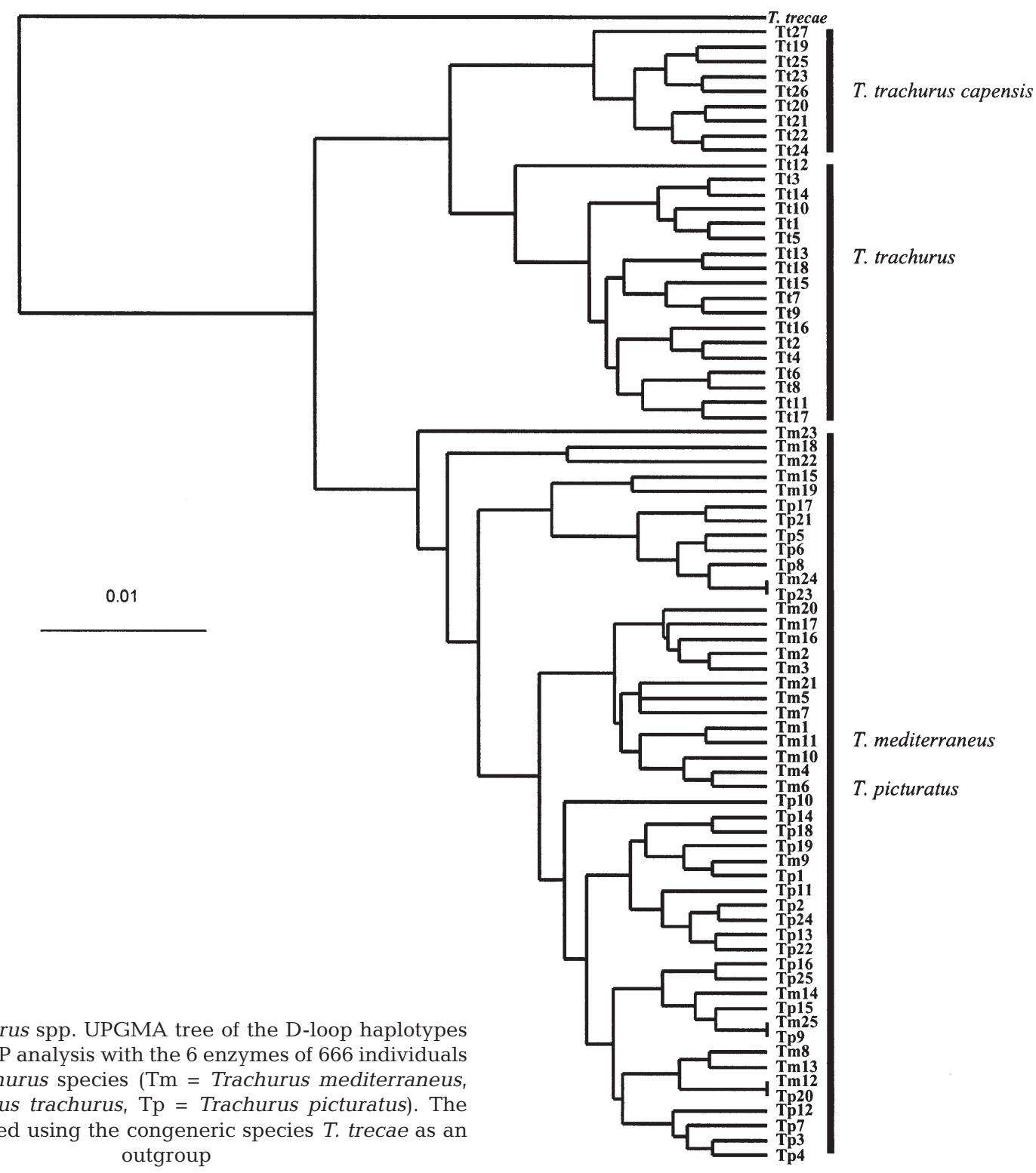

Fig 2. Trachurus spp. UPGMA tree of the D-loop haplotypes based on RFLP analysis with the 6 enzymes of 666 individuals of all 3 Trachurus species $(\mathrm{Tm}=$ Trachurus mediterraneus, $\mathrm{Tt}=$ Trachurus trachurus, $\mathrm{Tp}=$ Trachurus picturatus $)$. The tree was rooted using the congeneric species $T$. trecae as an outgroup

3 for T. picturatus (with total frequency $55.4 \%$ ). The majority of the recorded haplotypes were low frequency haplotypes, i.e. observed less than twice in different samples. Thus, 17 out of 27 haplotypes were unique (present in only 1 sample) for T. trachurus, 19 out of 25 for $T$. mediterraneus and 17 out of 25 for T. picturatus.

Haplotypic diversity values, estimated after the analysis of the 6 enzymes that discovered polymorphism (Tables 2, $3 \& 4$ ), were higher for Trachurus picturatus $(87.86 \pm 0.09 \%)$ than for $T$. trachurus $(79.60 \pm 0.04 \%)(81.17 \pm 0.03 \%$ excluding African samples of $T$. trachurus) and T. mediterraneus $(74.43 \pm 0.07 \%)$. Additionally, nucleotide diversity values estimated within Trachurus spp. populations were higher for $T$. picturatus $(1.33 \pm 0.00027 \%)$ than for T. trachurus $(0.93 \pm 0.00002 \%)(0.94 \pm 0.00002 \%$ excluding African samples of $T$. trachurus) or $T$. mediterraneus $(0.94 \pm 0.00006 \%)$. When the 6 mostly monomorphic enzymes were included in the analysis, the mean values of nucleotide diversity were $1.14 \%$ for $T$. picturatus, $0.79 \%$ for T. mediterraneus and $0.83 \%$ for T. trachurus.

All global and pairwise tests of sample differentiation did not result in a significant outcome for the 6 samples of Trachurus mediterraneus $(\mathrm{p}=0.662)$ and the 5 samples of $T$. picturatus ( $\mathrm{p}=0.886)$. On the other hand, the global test for the 12 samples of $T$. trachurus resulted in significant population differentiation ( $p<0.0001)$. This differentiation could be attributed to the inclusion of Namibian and South African populations since when these samples were omitted, 
the global test was not significant. Within European T. trachurus samples, only in the case of the VIIIb region were 5 out of the 9 pairwise tests statistically significant, but none of these was significant after the Bonferroni correction.

Results of the hierarchical analysis of molecular variance (AMOVA) for European Trachurus trachurus indicated that most of the variation is within samples $\left(F_{\mathrm{ST}}=0.008\right.$, Table 5). On the other hand, when African populations were added, a statistically significant amount of the variation $\left(F_{\mathrm{ST}}=0.307, \mathrm{p}<0.001\right)$ was due to differences between samples. For T. mediterraneus, all genetic variation was distributed within samples, while for $T$. picturatus only $2.4 \%$ of the variation was due to differences between samples without this value being statistically significant $(\mathrm{p}=0.051)$. Additionally, $F_{\text {ST }}$ values remained statistically non significant, even if samples were grouped according to Atlantic or Mediterranean origin (Table 5).

Simultaneously, the Mantel test showed that there was no correlation between the genetic and the geographical distance matrices for any species (Trachurus mediterraneus: $\mathrm{p}=0.095$, T. picturatus: $\mathrm{p}=0.44$, European T. trachurus: $\mathrm{p}=0.22$ ). Only when African samples of $T$. trachurus were included in the analysis, was there a positive correlation between genetic and geographical distances $(\mathrm{p}=0.005)$.

Table 5. Trachurus spp. Results of the hierarchical analysis of molecular variance with or without grouping. The probability (p) estimated from permutation tests as well as the F-statistics are given at each hierarchical level (Excoffier et al. 1992). Med. = Mediterranean. The phrases 'no structure' or 'Atlantic/ Med.' correspond to the a priori hypotheses/groupings that are tested

\begin{tabular}{|c|c|c|c|c|}
\hline Species & \multicolumn{2}{|c|}{ Source of variation } & Fixation index & $\mathrm{p}$ \\
\hline $\begin{array}{l}\text { T. trachurus \& } \\
\text { T. t. capensis }\end{array}$ & \multicolumn{2}{|l|}{ No structure } & $F_{\mathrm{ST}}=0.307$ & 0.000 \\
\hline \multirow[t]{4}{*}{ T. trachurus } & \multicolumn{2}{|l|}{ No structure } & $F_{\mathrm{ST}}=0.008$ & 0.167 \\
\hline & & Among regions & $F_{\mathrm{CT}}=0.002$ & 0.220 \\
\hline & \multirow[t]{2}{*}{$\begin{array}{l}\text { Atlantic/ } \\
\text { Med. }\end{array}$} & $\begin{array}{l}\text { Among samples/ } \\
\text { within regions }\end{array}$ & $F_{\mathrm{SC}}=0.004$ & 0.433 \\
\hline & & Within samples & $F_{\mathrm{ST}}=0.006$ & 0.220 \\
\hline \multirow[t]{4}{*}{ T. mediterraneus } & \multicolumn{2}{|l|}{ No structure } & $F_{\mathrm{ST}}=-0.003$ & 0.566 \\
\hline & & Among regions & $F_{\mathrm{CT}}=-0.008$ & 0.830 \\
\hline & \multirow[t]{2}{*}{$\begin{array}{l}\text { Atlantic/ } \\
\text { Med. }\end{array}$} & $\begin{array}{l}\text { Among samples/ } \\
\text { within regions }\end{array}$ & $F_{\mathrm{SC}}=-0.006$ & 0.700 \\
\hline & & Within samples & $F_{\mathrm{ST}}=-0.008$ & 0.822 \\
\hline \multirow[t]{4}{*}{ T. picturatus } & \multirow[t]{2}{*}{ No structure } & & $F_{\mathrm{ST}}=0.024$ & 0.051 \\
\hline & & Among regions & $F_{\mathrm{CT}}=0.007$ & 0.214 \\
\hline & \multirow[t]{2}{*}{$\begin{array}{l}\text { Atlantic/ } \\
\text { Med. }\end{array}$} & $\left\{\begin{array}{l}\text { Among samples/ } \\
\text { within regions }\end{array}\right.$ & $F_{\mathrm{SC}}=-0.008$ & 0.974 \\
\hline & & Within samples & $F_{\mathrm{ST}}=-0.007$ & 0.671 \\
\hline
\end{tabular}

A UPGMA tree based on the distance matrix of nucleotide divergence (DA) was constructed for all the 3 studied species (Fig. 3). For the 5 samples of Trachurus picturatus and the 6 samples of T. mediterraneus, no specific clustering of samples was observed. For $T$. trachurus populations, the samples clustered in 2 distinct clades, the one including the African samples (Namibia and South Africa) and the other consisting of the European samples. No geographical structuring was found within this clade.

\section{DISCUSSION}

\section{No levels of population differentiation within the 3 Trachurus species}

Analysis of the genetic structure of the 3 Trachurus species was performed both within and between the Mediterranean and Atlantic waters. The heterogeneity exact tests, the $F_{S T}$-based analysis and the Mantel tests did not reveal significant variation among samples within T. picturatus and T. mediterraneus or within European samples of $T$. trachurus. This phenomenon could be commonly attributed to high levels of current gene flow as a result of the species high dispersal abilities in the marine environment and the fact that marine waters are often viewed as boundless habitats, and therefore, an ongoing exchange of migrants is taking place (e.g. Àrnason \& Palsson 1996, Vis et al. 1997). Only the pairwise comparison of Namibian and South African samples to European T. trachurus samples resulted in significant differentiation $(p=0.005)$. This differentiation is consistent with the placement of African T. trachurus populations into a different subspecies known as Trachurus trachurus capensis expanding from the Gulf of Guinea to South Africa, indicating that enough time has elapsed for the African population to differentiate from the European populations. The lack of significant population structuring was also evident in the phylogentic trees (Fig. 3) that did not reveal pronounced phylogeographic structuring for $T$. mediterraneus and $T$. picturatus. For $T$. trachurus, 2 major genetic divisions were defined: one including the European populations grouped without any evident geographical meaning and the other, the African ones. 


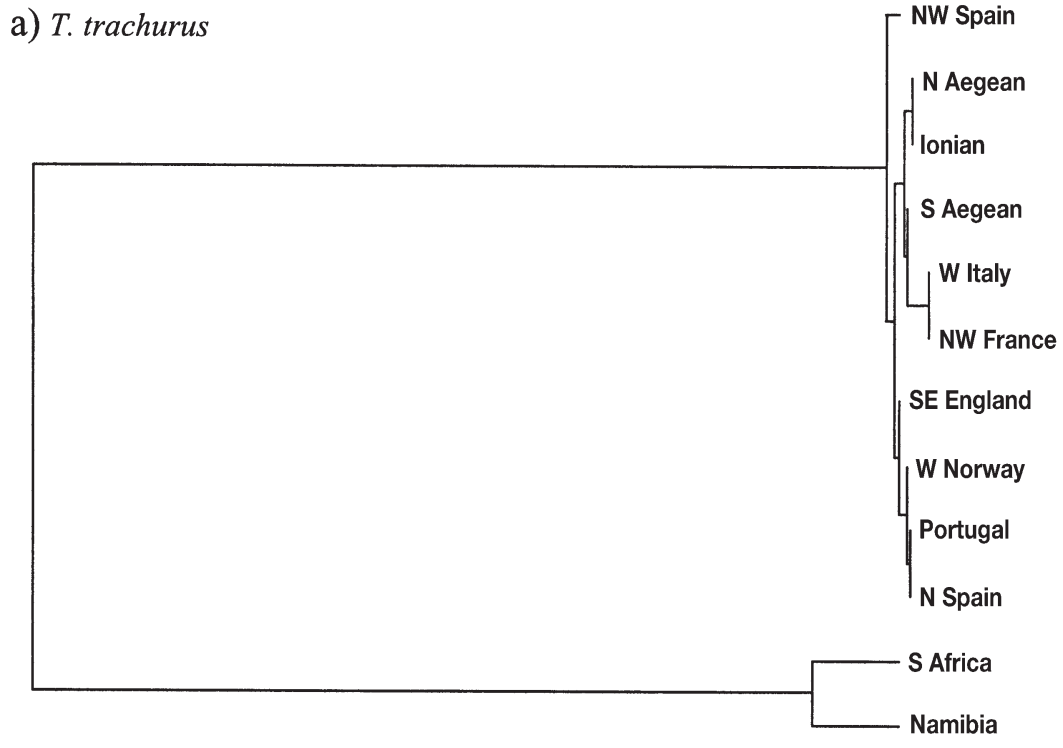

b) T. mediterraneus

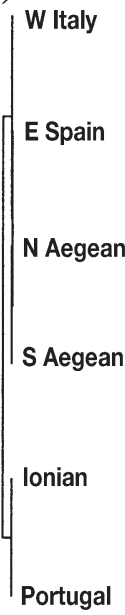

0.001

an

Fig 3. Trachurus spp. UPGMA phenograms clustering: (a) the 12 samples of Trachurus trachurus, (b) the 6 samples of T. mediterraneus and (c) the 5 samples of T. picturatus based on pairwise divergence values. ICES abbreviations are: Portugal (IXa), N Spain (VIIIc), NW Spain (VIIIb), NW France (VIIe), SE England $(\mathrm{IVb}-\mathrm{c}), \mathrm{W}$ Norway (IVa)

For a proportion of species presently occurring in both the Atlantic and the Mediterranean, the Strait of Gibraltar represents a corridor sufficient for gene flow; thus, an ongoing exchange of individuals between the 2 seas is taking place (see reviews in Borsa et al. 1997b). Species of the same family with very similar biological features may react differently to oceanographic conditions. A very characteristic example is the case of 5 sparidae species (Bargelloni et al. 2003). For 3 (Dentex dentex, Lithognathus mormyrus and Spondyliosoma cantharus) out of 5 species of the family, no free mixing between the Mediterranean and the Atlantic popula- tions is taking place as hydrographic conditions lower the rate of gene flow between them at such levels that prevent their genetic homogenization and thus, act as a force for the maintenance of genetic differentiation. On the contrary, the other 2 congeneric sparidae species (Pagellus bogaraveo and Pagrus pagrus) display no differentiation at all. For all 3 Trachurus species, the Gibraltar Strait does not present a phylogeographic boundary, as there was no sign of Atlantic-Mediterranean division. Specific life history traits may provide Trachurus species with flexibility to oceanographical constraints and give them the ability to migrate across them.

Another (not necessarily exclusive) scenario for this lack of differentiation between the Atlantic and Mediterranean populations could be the effect of recent colonization without sufficient time for the Mediterranean populations to diverge. In order to test this scenario, Tajima's D (Tajima 1989) values were estimated for all studied samples of the 3 Trachurus species to search for departures from mutationdrift equilibrium (Tajima's $D$ values should be significantly negative). None of Tajima's $D$ values was significantly negative for any of the samples under study. This means that the shallow population differentiation detected for the 3 species is not a consequence of a recent colonization but probably reflects populations in long and stable demographic equilibrium.

The fact that conclusions are often based on the evidence of 1 methodology and 1 single mtDNA marker is usually criticized. The present results are consistent with the results obtained by the sequence analysis of cytochrome $b$ of mtDNA (Karaiskou et al. 2003). Global and pairwise tests obtained from the analysis of 9 European samples with a comparable although restricted sampling scheme (NW Spain and SE England were not included) of the 3 Trachurus species did not reveal marked differences within T. mediterraneus $(\mathrm{p}=0.980)$ and $T$. trachurus $(\mathrm{p}$ $=0.824)$. The test for $T$. picturatus resulted in significant population differentiation $(p=0.026)$ but it was attributed only to the pairwise comparison of Portugal to the S Aegean Sea samples, probably due to the 
small sample size. Thus, the shallow genetic structure is supported by concordant evidence of sequence and RFLP data of 2 different mtDNA markers.

\section{Patterns of genetic diversity in Trachurus species}

A typical phenomenon of many marine species, both vertebrate and invertebrate, is the high level of within population haplotypic diversity. This has been observed for many fish species (Camper et al. 1993, Zwanenburg et al. 1992, Grant \& Waples 2000) and is also evident in the case of the 3 studied Trachurus species (Tables $2,3 \& 4$ ). However, the majority of the haplotypes $(63,76$ and $68 \%$ for $T$. trachurus, $T$. mediterraneus and $T$. picturatus, respectively) occur at low frequencies. Explanations for the occurrence of high diversity values and of large numbers of low frequency haplotypes may lie in the enormous population sizes of marine organisms, which may cause retention of numerous haplotypes and result in undersampling of the populations (Bucklin \& Wiebe 1998). This is true especially in the case of $T$. trachurus which is a fairly long-lived species, reaching a maximum age of over 30 yr (Eltink \& Kuiter 1989) and thus, occasional strong year classes (such as in 1982, Abaunza et al. 2003) lead to high abundance of the species. Additionally, levels of nucleotide diversity obtained after the analysis of the 6 (or even the 12) enzymes, were high for all 3 species and close to the values obtained after the sequence analysis of the D-loop region of the species Scomber scombrus (Percirformes), where values ranged from 1.6 to $3 \%$ (mean $h=0.76$ and $\pi=2.8 \%$ : Nesbø et al. 2000). The observed values of the haplotype and nucleotide diversity are within the range of values reported in a review of mtDNA variation in 32 marine teleost species (range $h=0.70-1$ and $\pi=0.80$ to $3.20 \%$ ) by Grant \& Bowen (1998). According to these authors, high haplotype and nucleotide diversity values are typical for large stable populations with a long evolutionary history or are the result of secondary contact between previously extended geographic isolated populations, which, however, is unlikely for middle pelagic Trachurus species because of the high dispersal capabilities of the species (Bas 1995). Additionally, all populations shared some common haplotypes with high frequencies and therefore, there was no evidence of different past-history refugia. Thus, the high diversity values probably reflect large and stable populations through time and further supports previous conclusions based on Tajima's $D$ values.

The values of haplotype diversity $(87.86 \%)$ as well as nucleotide diversity found in the samples of Trachurus picturatus (average $1.33 \%$ ) were higher than those found in the other 2 species. This result is in agreement with the results obtained from the sequence analysis of cytochrome b of the 3 species (Karaiskou et al. 2003). This might be a reflection of the fact that $T$. picturatus is subjected to lower levels of fishing mortality as presumed from the reported annual catch statistics (Food and Agriculture Organization, www.fao.org), which are an order of magnitude less than those of $T$. trachurus and T. mediterraneus. Thus, it is quite likely that $T$. picturatus maintains a larger population size resulting in higher levels of genetic diversity. However, this hypothesis cannot be tested with the data at hand because T. picturatus is not subjected to annual assessments in the NE Atlantic. Thus, no fish mortality estimates are available. One should, however, also not exclude as a possible explanation that higher haplotypic and nucleotide values might reflect an intrinsic characteristic of $T$. picturatus (e.g. lower levels of natural mortality).

The amount of haplotypic diversity revealed after the sequence analysis of cytochrome $b$ (Karaiskou et al. 2003) for Trachurus picturatus, $T$. trachurus and $T$. mediterraneus $(64.40,26.66$ and $24.10 \%$, respectively) was considerably lower compared to the D-loop, especially for $T$. trachurus and $T$. mediterraneus. The same status existed for nucleotide diversity values of cytochrome $\mathrm{b}$, within populations of $T$. picturatus (average $0.47 \%)$, $T$. trachurus $(0.13 \%)$ or $T$. mediterraneus $(0.11 \%)$. This is a well-documented fact because of the higher mutation rate in the D-loop, which leads to higher polymorphism and thus, to a larger number of haplotypes. Additionally, it could be due to lower sample sizes in the cytochrome $b$ analysis.

\section{Lack of congruence between genetic and ICES stock data}

It is assumed that there are 3 distinct stocks of Trachurus trachurus in the NE Atlantic (ICES 1999): (1) the southern horse mackerel around the Iberian peninsula (ICES Divisions: VIIIc and IXa); (2) the western horse mackerel in the Norwegian Sea, northern North Sea, west and south off the British Isles, western Channel and west off France (ICES Divisions: IIa, IIIa, Vb, IVa, VIa, b, VIIa to c, e to k and VIIIa, b, d, e); and (3) the North Sea horse mackerel, mainly restricted to the central and southern North Sea, and eastern English Channel (ICES Divisions: IVb, c and VIId). This separation of stocks was based on circumstantial evidence, such as egg distribution and temporo-spatial distribution of fishery or morphological differences (Kerstan 1991). Therefore, the need for stronger biological justification has been recognized.

An attempt was made to evaluate the existence of 3 different stocks according to ICES, by using genetic analysis of samples from different geographical areas 
within each of the 3 determined units. Thus, the assumed southern stock was represented (Fig. 1) by samples obtained from areas VIIIc and IXa, the Northern stock by a sample from the area between IVb and $\mathrm{IVC}_{\mathrm{C}}$, and the western stock by samples from areas VIIIb, VIIe and IVa. The test for differences between the 3 assumed Atlantic stocks (samples within stocks were pooled) resulted in significant population differentiation $(p=0.03)$. However, this could be attributed only to the pairwise tests of the VIIIb area to the other areas, as when this region was omitted, no global and/or pairwise test was statistically significant. This could probably be due to sampling error as can be concluded in the case of the $\mathrm{S}$ Aegean sample. In our initial experiments, the pairwise comparison of the $\mathrm{S}$ Aegean to the other studied populations was also statistically significant but when the sample size was increased (63 individuals), no significant population differentiation was detected for European Trachurus trachurus.

Thus, the data obtained by the global test of differentiation did not support the initial hypothesis of 3 different stocks for Trachurus trachurus as these 6 sampling areas in Atlantic waters could not be considered as reproductively isolated. These results probably suggest a revision of ICES stock boundaries. This was also evident in the case of European Merluccius merluccius (Lundy et al. 1999), where microsatellite data supported a different structure than the one determined by ICES.

According to Waples (1998), patterns of differentiation that are consistent across time will unlikely be due to sampling artifacts. Lundy et al. (2000) have demonstrated that the spatial patterns obtained for Merluccius merluccius are not temporally stable since very high levels of interannual differentiation are detected. Thus, it could not yet be supported that the European populations of Trachurus trachurus could be managed as a single stock and not as 3 different stocks. It is necessary to ensure that patterns seen here of unlimited migration are temporally stable, both annually and during spawning seasons, when mature adults migrate to common spawning sites which are far from feeding grounds in the case of $T$. trachurus (Abaunza et al. 2003). From a management perspective, it is also important to stress that whether the hypothesis of recent colonization of the Mediterranean from the Atlantic was true, then the Mediterranean and the Atlantic stocks should be managed separately.

\section{Phylogenetic relationships}

The phylogenetic analyses, based on distance and maximum parsimony methods, revealed the existence of 2 clusters: one with haplotypes of Trachurus trachu- rus, and the other including both T. mediterraneus and T. picturatus haplotypes. This result is not in absolute accordance with the results obtained by the sequence data of cytochrome $b$ where the 22 haplotypes determined for the 3 species clustered in 3 distinct lineages (Karaiskou et al. 2003). A plausible explanation for this discrepancy is that nucleotide saturation in the D-loop region obscures the usefulness of this segment for closely related sequences. This phenomenon might have also decreased the number of species-specific sites overall, resulting in low bootstrap values in the UPGMA phylogenetic tree of haplotypes. However, one should not forget the inherent limitations of the RFLP methodology; a phylogenetic analysis based on the sequence of the D-loop region might increase the bootstrap values. The same discrepancy was found for rainbow fishes by Zhu et al. (1994). These authors found that the most probable cause of the discrepancy is rapid saturation of transitions in the D-loop, presumably as a result of a more biased base composition (e.g. higher A + T content) compared to cytochrome b.

The clear discrimination of Trachurus trachurus was, however, also evident by the existence of species-specific enzymes, such as DdeI and HhaI, that can be used to discriminate $T$. trachurus from the other 2 species, while no possible enzyme was found to discriminate between T. mediterraneus and T. picturatus. Additionally, the shared haplotypes between $T$. mediterraneus and $T$. picturatus further reinforced the closer relationship of these 2 species compared to T. trachurus, which may have differentiated earlier from the common ancestor than the other 2 species (Karaiskou et al. 2003).

\section{Conclusions and implications for management}

As discussed in detail by Waples (1998), the genetic signal indicating population structure is relatively weak for species displaying a high dispersal capacity. It has been assumed that the usually high level of genetic variation observed at microsatellite loci would provide enough resolution power to increase the genetic signal and hence, the likelihood of correctly describing the population structure of marine fishes. Thus, a further analysis using microsatellite data may maximize the chances of detecting genetic differences among Trachurus spp. populations, since even such a highly polymorphic region as the D-loop region appears to reveal population differentiation less often than microsatellites with similar levels of variability (Hauser \& Ward 1998). Hauser et al. (2001) demonstrated that mtDNA and microsatellite data did not support the same results in the Atlantic herring Clupea harengus, most likely due to differences in mutation 
rate and demographic dynamics of the 2 marker systems, and thus underlying the need for simultaneous application of the 2 markers to the same sample sets. Additionally, both biological and ecological features (e.g. growth and mortality) should be taken into consideration when addressing management issues.

The results based on the RFLP analysis of the D-loop region showed no clear genetic structuring between the studied samples of the 3 Trachurus species (T. trachurus, T. mediterraneus and T. picturatus). Additionally, no Atlantic-Mediterranean population differentiation was observed. However, based on the fact that every methodology and genetic system selected to uncover the population structure may not lead to detectable genetic differences, extreme caution is suggested, when policy decisions need to be taken. Thus, despite the lack of differentiation, it would be wise to apply precautionary management approaches until the present information is also compared with a number of genetic systems and possible techniques.

Acknowledgements. We thank C. Stergiou for his help with sampling and for his valuable advice. Additionally, we thank A. Kouvatsi for her valuable suggestions. Furthermore, we thank J. Leonardos, C. Karlou, D. Moutopoulos and local fishermen for their help with sampling. We are also grateful to E. Garcia-Vazquez, P. Lopes, P. Alvarez, M. Arculeo, K. Jostard, G. Dahle and H. Kaiser for sending us samples of Trachurus species. This project is financially supported by the EU:QLKSCT 1999-01157 program under the coordination of E. GarciaVazquez (University of Oviedo, Spain). Finally, we would like to thank 3 anonymous reviewers and the contributing editor for their suggestions for improving this manuscript.

\section{LITERATURE CITED}

Abaunza P, Gordo L, Karlou-Riga C, Murta A and 8 others (2003). Growth and reproduction of horse mackerel, Trachurus trachurus (Carangidae). Rev Fish Biol Fish 13: $27-61$

Àrnason E, Palsson S (1996) Mitochondrial cytochrome b DNA sequence variation of Atlantic cod Gadhus morhua, from Norway. Mol Ecol 5:715-724

Bargelloni L, Alarcon JA, Alvarez MC (2003) Discord in the family Sparidae (Teleostei): divergent phylogeographic patterns across the Atlantic-Mediterranean divide. J Evol Biol 16:1149-1158

Bas C (1995) Ecological structures: expansion and replacement. Sci Mar 59:373-380

Belkhir K (1999) GENETIX V 4.0. Laboratoire Genome, Populations, Interactions, CNRS UPR 9060. Université de Montpellier

Bembo DG, Carvalho GR, Snow M, Cingolani N, Pitcher TJ (1995) Stock discrimination among European anchovies, Engraulis encrasicolus, by means of PCR-amplified mitochondrial DNA analysis. Fish Bull 94:31-40

Borsa P, Blanquer A, Berrebi P (1997a) Genetic structure of the flounders Platichthys flesus and $P$. stellatus at different geographical scales. Mar Biol 129:233-246

Borsa P, Naciri M, Bahri L, Chikhi L, Garcia de Leon FJ,
Kotoulas G, Bonhomme F (1997b) Zoogeographie infraspecifique de la mer Mediterranee. Analyse des donnees genetiques populationnelles sur seize especes AtlantoMediterraneennes (Poissons et Invertebres). Vie Milieu 47:295-305

Bucklin A, Wiebe PH (1998) Low mitochondrial diversity and small effective population sizes of the copepods, Calanus finmarchicus and Nannocalanus minor: possible impact of climatic variation during recent glaciation. J Hered 89: 383-392

Camper JD, Barber RC, Richardson LR, Gold JR (1993) Mitochondrial DNA variation among red snapper (Lutjanus campechanus) from the Gulf of Mexico. Mol Mar Biol Biotechnol 2:154-161

Chow S, Clarke ME, Walsh PJ (1993) PCR-RFLP analysis of thirteen western Atlantic snappers (subfamily Lutjaninae): a simple method for species and stock identification. Fish Bull 91:619-627

Eltink ATGW, Kuiter C (1989). Validation of aging techniques on otoliths of horse mackerel (Trachurus trachurus L.). ICES CM 1989/H:43, p15

Excoffier L, Smouse P, Quattro JM (1992) Analysis of molecular variance inferred from metric distances among DNA haplotypes: application to human mitochondrial DNA restriction data. Genetics 131:479-491

Felsenstein J (1995) PHYLIP (Phylogeny Inference Package), version 3.57c. Department of Genetics, SK-50, University of Washington, Seattle, WA

Froese R, Pauly D (eds) (2001) FishBase. World Wide Web electronic publication, www.fishbase.org

Grant WS, Bowen BW (1998) Shallow population histories in deep evolutionary lineages of marine fishes: insights from sardines and anchovies and lessons for conservation. J Hered 89:415-426

Grant WS, Waples RS (2000) Spatial and temporal scales of genetic variability in marine and anadromous species: implications for fisheries oceanography. In: Harrison PJ, Parsons TR (eds) Fisheries oceanography: an integrative approach to fisheries ecology and management. Blackwell Science, Oxford, p 63-93

Graves JE (1998) Molecular insights into the population structures of cosmopolitan marine fishes. J Hered 89:427-437

Graves JE, Ferris SD, Dizon AE (1984) Close genetic similarity of Atlantic and Pacific skipjack tuna (Katsuwonus pelamis) demonstrated with restriction endonuclease analysis of mitochondrial DNA. Mar Biol 79:315-319

Grewe PM, Hampton J (1998) An assessment of bigeye (Thunnus obesus) population structure in the Pacific Ocean based on mitochondrial DNA and DNA microsatellite analysis. SOEST (School of Ocean \& Earth Science Technology) Publ 98-05, JIMAR (Joint Institute for Marine \& Atmospheric Research) Contrib 98-320. University of Hawaii at Manoa, HI

Hauser L, Turan C, Carvalho GR (2001) Haplotype frequency distribution and discriminatory power of two mtDNA fragments in a marine pelagic teleost (Atlantic herring, Clupea harengus). Heredity 87:621-630

Hauser L, Ward RD (1998) Population identification in pelagic fish: the limits of molecular markers. In: Carvalho G. (ed) Advances in Molecular Ecology. IOS Press, Amsterdam, p 191-224

Hillis DM, Moritz C, Mable BK (1996) Molecular Systematics 2nd edn. Sinauer Associates, Sunderland, MA

ICES (1999) Report of the working group on the assessment of mackerel, horse mackerel, sardine and anchovy. ICES C.M. 1999/ACFM: 6, p 464

Karaiskou N, Apostolidis A, Triantafyllidis A, Kouvatsi A, Tri- 
antaphyllidis C (2003) Genetic identification and phylogeny of three species of the genus Trachurus based on mtDNA analysis. Mar Biotechnol 5:493-504

Kerstan M (1991) Age, growth, maturity and mortality estimates of horse mackerel (Trachurus trachurus) from the waters west of Great Britain and Ireland in 1984. Arch Fischwiss 36:115-154

Kotoulas G, Magoulas G, Tsimenides N, Zouros E (1995) Marked mitochondrial DNA differences between Mediterranean and Atlantic populations of the swordfish, Xiphias gladius. Mol Ecol 4:473-481

Lundy CJ, Moran P, Rico C, Milner RS, Hewitt GM (1999) Macrogeographical population differentiation in oceanic environments: a case study of European hake (Merluccius merluccius), a commercially important fish. Mol Ecol 8: $1889-1898$

Lundy CJ, Rico C, Hewitt GM (2000) Temporal and spatial genetic varaition in spawning grounds of European hake (Merluccius merluccius) in the Bay of Biscay. Mol Ecol 9:2067-2079

Magoulas A, Tsimenides N, Zouros, E (1996) Mitochondrial DNA phylogeny and the reconstruction of the population history of a species: the case of the European anchovy (Engraulis encrasicolus). Mol Biol Evol 13:178-190

Mantel N (1967) The detection of disease clustering and a generalised regression approach. Cancer Res 27:209-220

Massé J, Koutsikopoulos C, Patty W (1996) The structure and spatial distribution of pelagic fish schools in multispecies clusters: an acoustic study. ICES J Mar Sci 55:155-160

McElroy D, Moran P, Bermingham E, Kornfield J (1991) The Restriction Enzyme Analysis package, version 4.0. University of Maine, Orono, ME

Meyer A (1993) Evolution of mitochondrial DNA in fish. In: Hochachka PW, Mommsen TP (eds) Biochemistry and molecular biology of fish. Elsevier Science Publishers, Amsterdam, p 1-38

Naciri M, Lemaire C, Borsa P, Bonhomme F (1999) Genetic study of Atlantic/Mediterranean trantition in sea bass (Dicentrarchus labrax). J Hered 90:591-596

Nei M (1987) Molecular evolutionary genetics. Columbia University Press, New York

Nei M, Tajima F (1981) DNA polymorphism detectable by restriction endonucleases. Genetics 97:145-163

Nesbø CL, Rueness EK, Iversen SA, Skagen WD, Jakobsen KS (2000) Phylogeography and population history of Atlantic mackerel (Scomber scombrus L.): a genealogical approach reveals genetic structuring among the eastern Atlantic stocks. Proc R Soc Lond 267:281-292

Perez-Losada M, Guerra A, Carvalho GR Sanjuan A, Shaw PW (2002) Extensive population subdivision of the cuttlefish Sepia officinalis (Mollusca: Cephalopoda) around the

Editorial responsibility: Simon Archer (Contributing Editor), Guldford, UK
Iberian Peninsula indicated by microsatellite DNA variation. Heredity 89:417-424

Quesada H, Gallagher C, Skibinski DAG, Skibinski DOF (1998) Patterns of polymorphism and gene flow of gender associated mitochondrial DNA lineages in European mussel populations. Mol Ecol 7:1041-1051

Raymond M, Rousset F (1995) An exact test for population differentiation. Evolution 49:1280-1283

Rice WR (1989) Analysing tables of statistical tests. Evolution 43:223-225

Rozen S, Skaletsky H (2000) Primer3 on the web for general use and for biologist programmers. In: Krawetz S, Misener $\mathrm{S}$ (eds) Bioinformatics methods and protocols methods in molecular biology. Humana Press, Totowa, NJ p 365-386

Saitou N, Nei M (1987) The neighbor-joining method: a new method for reconstructing phylogenetic trees. Mol Biol Evol 4:406-425

Schneider S, Roessli D, Excoffier L (2000) Arlequin V 2.0. A software for population genetics data analysis. Genetics and Biometry Laboratory, University of Geneva

Taggart JB, Hynes RA, Prodohl PA, Ferguson A (1992) A simplified protocol for routine total DNA isolation from salmonid fishes. J Fish Biol 40:963-965

Tajima F (1989) Statistical method for testing the neutral mutation hypothesis by DNA polymorphism. Genetics 123:585-595

Viette M, Giulianini PG, Ferrero EA (1997) Reproduction biology of scad, Trachurus mediterraneus (Teleostei, Carangidae), from the Gulf of Trieste. ICES J Mar Sci 54:267-272

Vis ML, Carr SM, Bowering WR, Davidson, WS (1997) Greenland halibut (Reinhartius hippoglossides) in the North Atlantic are genetically homogenous. Can J Fish Aquat Sci 54:1813-1821

Waldron EM, Kerstan M (2001) Age validation in horse mackerel (Trachurus trachurus) otoliths. ICES J Mar Sci 58:806-813

Waples R (1998) Separating the wheat from the chaff: Patterns of genetic differentiation in high gene flow species. J Hered 89:438-450

Zane L, Ostellari L, Maccatrozzo L (2000) Genetic differentiation in a pelagic crustacean (Meganyctiphanes norvegica: Euphausiacea) from the North East Atlantic and the Mediterranean Sea. Mar Biol 136:191-199

Zhu D, Jamison BGM, Hugall A, Moritz C (1994) Sequence evolution and phylogenetic signal in control region and cytochrome $b$ sequences of rainbow fish (Melanotaeniidae). Mol Biol Evol 11:672-683

Zwanenburg KCT, Bentzen P, Wright JM (1992) Mitochondrial DNA differentiation in western north Atlantic populations of haddock (Melanogrammus aeglefinus). Can J Fish Aquat Sci 49:2527-2537

Submitted: February 20, 2004; Accepted: July 7, 2004

Proofs received from author(s): September 27, 2004 